\title{
PEMBELAJARAN KOOPERATIF STAD DENGAN STRATEGI PENUGASAN MULTI LEVEL INSTRUCTION PADA MATERI MATEMATIKA
}

\author{
Randy Saputra Mahmud, Ahmad Syamsuadi, Nursakiah \\ Universitas Muhammadiyah Makassar, Jl. Sultan Alauddin No. 259
}

Email: randysmahmud@yahoo.co.id

\begin{abstract}
The purpose of this study was to determine the activities, responses, and student learning outcomes with multi level instruction learning. Multi level instruction assignment learning strategy is a selling system adoption from multi level marketing strategy with special characteristics that there are students in first level and second level downlines and a teacher as an upline. Type of research is quasi-experimental by comparing two experimental groups. Experimental group one was given the STAD model with multi level instruction, and the other group was given regular STAD model. The research instruments used were student activity observation sheets, student response questionnaires, and learning outcomes test. The data obtained were analyzed descriptively and inferentially. The result indicates that both of them are effective to be applied in mathematic learning, but inferentially the outcomes of the experiment group one was higher than the experiment group two.
\end{abstract}

Keyword: cooperative STAD, multi level instruction, peer tutoring.

\section{PENDAHULUAN}

Salah satu mata pelajaran di sekolah yang memerlukan strategi khusus dalam pembelajaran adalah matematika. Konsep-konsep yang telah tersusun dalam matematika merupakan konsep yang banyak dibutuhkan pada materi keilmuan yang lain. Namun, kendala yang ditemukan di kelas adalah tidak semua siswa dapat dengan mudah memahami materi matematika yang diberikan. Hal ini disebabkan oleh beberpa faktor, diantaranya gaya belajar anak, manajemen waktu belajar, dan interaksi sosial anak dengan lingkungan dimana ia belajar yang kurang tepat.

Pembelajaran matematika dianggap berhasil apabila siswa yang sebelumnya tidak tahu akhirnya menjadi tahu mengenai konsep matematika yang diajarkan. Keaktifan siswa dalam proses pembelajaran merupakan satu hal yang penting bagi guru untuk mengetahui paham atau tidak seorang siswa terhadap materi yang diberikan. Namun 
kenyataan yang ditemukan di kelas adalah terdapat siswa yang aktif dan bersemangat dalam proses pembelajaran dan terdapat siswa yang cenderung pasif, pemalu dan pendiam. Selain itu, pemilihan waktu belajar juga sangat berperan penting dalam mempengaruhi cepat/lambat daya serap siswa terhadap pelajaran. Oleh karena itu diperlukan stategi yang tepat khususnya dalam pembelajaran matematika agar hasil pembelajaran lebih maksimal. Salah satu pembelajaran yang dapat digunakan untuk mengatasi masalah tersebut diatas adalah model pembelajaran kooperatif tipe STAD dengan strategi penugasan multi level instruction.

Pembelajaran kooperatif Student Teams-Achievement Divisions (STAD) memiliki komponen utama presentasi kelas, adanya kelompok, kuis, skor kemajuan individual, dan rekognisi team (Slavin, 2010). Presentasi kelas merupakan pengajaran langsung atau diskusi pelajaran yang dipimpin oleh guru, presentasi kelas ini haruslah benarbenar berfokus pada unit STAD dan para siswa harus benar-benar menyadari bahwa siswa harus memberi perhatian penuh selama persentasi kelas karena akan sangat membantu dalam mengerjakan kuis-kuis yang akan diberikan. Kelompok terdiri dari 4 sampai 5 siswa yang dikondisikan mewakili tingkat kognitif, kinerja akademik, jenis kelamin, ras dan etnis yang beragam. Pemberian kuis setelah sekitar satu atau dua periode setelah guru memberikan presentasi kelas. Skor kemajuan individual ditujukan untuk memberikan kepada siswa tujuan kinerja yang dapat dicapai apabila bekerja lebih giat. Rekognisi kelompok ditujukan untuk memberikan sertfikat atau bentuk penghargaan yang lain apabila skor rata-rata kelompok mencapai kriteria tertentu.

Secara garis besar, langkah-langkah pembelajaran kooperatif tipe STAD terdiri atas sebuah siklus instruksi kegiatan regular yang dapat ditunjukkan sebagai berikut: (1) Mengajar, waktu yang dibutuhkan untuk pengajaran 1 sampai 2 periode kelas, dengan gagasan utama menyampaikan pelajaran atau materi. (2) Belajar kelompok, waktu yang diperlukan untuk belajar dalam kelompok adalah 1 sampai 2 periode kelas dengan gagasan utama adalah siswa belajar dalam kelompok. (3) Tes, waktu yang diperlukan untuk tes atau ujian adalah 1/2 sampai 1 periode kelas dengan gagasan utama adalah siswa mengerjakan kuis secara individual. Perhitungan skor individual dan kelompok sebaiknya dilakukan sesegera mungkin setelah kuis kembali dikumpulkan dan sebelum kelas berakhir. (4) Rekognisi kelompok, bertujuan untuk menghitung skor kemajuan individual dan skor kelompok serta memberikan sertifikat atau bentuk penghargaan 
kelompok lainnya. Tiga macam tingkatan penghargaan yang dapat diberikan berdasarkan rata-rata poin kemajuan anggota kelompok yaitu "KELOMPOK BAIK", “KELOMPOK SANGAT BAIK”, dan “KELOMPOK SUPER”.

Pembelajaran dengan strategi penugasan multi level instruction pada penelitian ini merupakan pengembangan dari pembelajaran tutor sebaya dengan menerapkan sistem multi level marketing dalam pemasaran produk. Strategi seperti ini umumnya telah digunakan oleh pesantren untuk materi bimbingan halaqah, setoran hafalan harian dan bimbingan baca kitab. Pembelajaran kooperatif STAD dengan strategi penugasan multi level instruction yang mengadopsi sistem penjualan produk dengan teknik multi level marketing ini memiliki ciri khas terdapat siswa upline, siswa downline, persentase materi/tugas dari upline kepada downline, pemberian bonus, waktu dan tempat persentase materi yang fleksibel, siswa saling bertutor sebaya, dan persaingan sehat untuk dapat naik ke level selanjutnya.

Pembelajaran dengan strategi penugasan multi level instruction memiliki ciri khas adanya interaksi antara siswa dalam pembelajaran, dari siswa yang bertindak sebagai upline kepada siswa yang bertindak sebagai downline. Penentuan peran siswa sebagai upline atau downline ditentukan setelah guru memberikan tes kemampuan awal. Siswa yang bertindak sebagai upline adalah siswa yang memiliki skor tes kemampuan awal lebih tinggi dibanding siswa yang lain atau siswa yang lebih cepat memahami materi dibanding siswa yang lain. Sedangkan siswa yang bertindak sebagai downline adalah siswa yang memiliki kognitif lemah atau agak lambat dalam memahami materi yang diberikan. Seorang upline mengatasi sekelompok downline yang terdiri dari 4-5 orang. Banyak kelompok downline ditentukan dari banyaknya upline. Jika siswa yang akan menjadi downline terlalu banyak, maka siswa tersebut dapat diklasifikasikan lagi ke dalam tingkatan downline, misalnya downline tingkat 1 dan downline tingkat 2. Kondisi yang terjadi dalam pembelajaran adalah adanya kegiatan saling bertutor sebaya antara upline dan downline yang merupakan inti dari kegiatan pembelajaran ini. "Peer learning is used to describe cooperative learning involving joint projects, or more senior student tutoring another junior student" (Petocz, dkk, 2012), bahwa tutor sebaya menggambarkan pembelajaran kooperatif dalam menyelesaikan suatu tugas bersama antara siswa dengan tingkat pendidikan yang sama, atau oleh siswa upline kepada siswa downline. Adapun manfaat yang diperoleh dengan kegiatan interaksi bertutor sebaya 
adalah : (1) "When students were working with a partner, they had someone else to ask for help rather than asking me" (Lafleur \& Bluffs, 2010: 1), bahwa ketika siswa saling bekerja bersama, siswa dapat meminta bantuan tanpa ada perasaan segan. (2) "He who teaches others, teaches himself" (Comenius dalam Gordon, 2005). "for the tutors, it is learning by teaching” (Topping, 2011), tutor sebaya merupakan proses belajar yang efektif bagi diri siswa sendiri, sarana belajar sambil mengajar dan siswa upline dapat memahami bahwa bantuan kepada downline akan semakin mempermantap penguasaan mereka terhadap materi. (3) "A peer-tutor could provide individual help to a peerstudent who was experiencing dificulties. As a result, the rest of the peer-students could continue to follow the main theme" (Evans, 2001), bahwa dengan bertutor sebaya dapat membantu siswa untuk mengatasi kesulitan belajar dan hasil dari tutor sebaya adalah siswa yang mengalami kesulitan belajar dapat melanjutkan untuk mengikuti materi yang akan diajarkan. (4) "During peer tutoring the reduction in management time, the high level of effective work time and the high percentage of success and feedback leads to high rate of academic learning time" (Duran, 2010), dapat mengefektifkan waktu dalam mengulangi penjelasan materi bagi siswa yang belum memahami materi. (5) "An onsite peer tutor is someone enrolled in the same course, with similar demographics, offering tutoring in the classroom before or after class" (Young, 2011). Tutor sebaya dapat dilakukan dalam ruangan kelas maupun diluar jam sekolah. Selain itu, dengan adanya kelompok bantu sebaya dapat "menciptakan ruang kelas yang tidak sepi, tapi semangat dan kinerja membaik" (Johnson, 2008).

Skema interaksi siswa dalam pembelajaran multi level instruction, direvisi dan dibentuk kembali sebagaimana yang diperlihatkan pada Gambar 1. Upline dalam penelitian ini adalah seseorang yang bertanggung jawab secara menyeluruh kepada seluruh downline pada pelajaran matematika dengan menggunakan pembelajaran multi level instruction, dalam hal ini yang bertindak sebagai upline adalah guru mata pelajaran matematika. Downline dalam penelitian ini adalah siswa yang menerima langsung pembelajaran dari guru dan saling berdiskusi dalam pembelajaran. Downline dibedakan menjadi beberapa tingkatan yaitu downline tingkat satu, downline tingkat dua, downline tingkat tiga, dan seterusnya. Namun dalam penelitian ini agar lebih mudah dalam mengontrol dan mengamati, penulis membatasi downline sampai pada downline tingkat dua. Downline tingkat satu adalah siswa yang memiliki kognitif lebih 
baik dibanding siswa yang lain. Kriteria siswa memiliki kognitif lebih baik didasarkan pada nilai siswa pada tes kemampuan awal dan berdasarkan rekomendasi dari guru penanggung jawab mata pelajaran matematika. Downline tingkat dua adalah siswa yang memiliki kognitif dari menengah sampai ke bawah. Adapun langkah-langkah pembelajaran multi-level intruction yang dikutip dari NWT Teacher Induction adalah sebagai berikut:

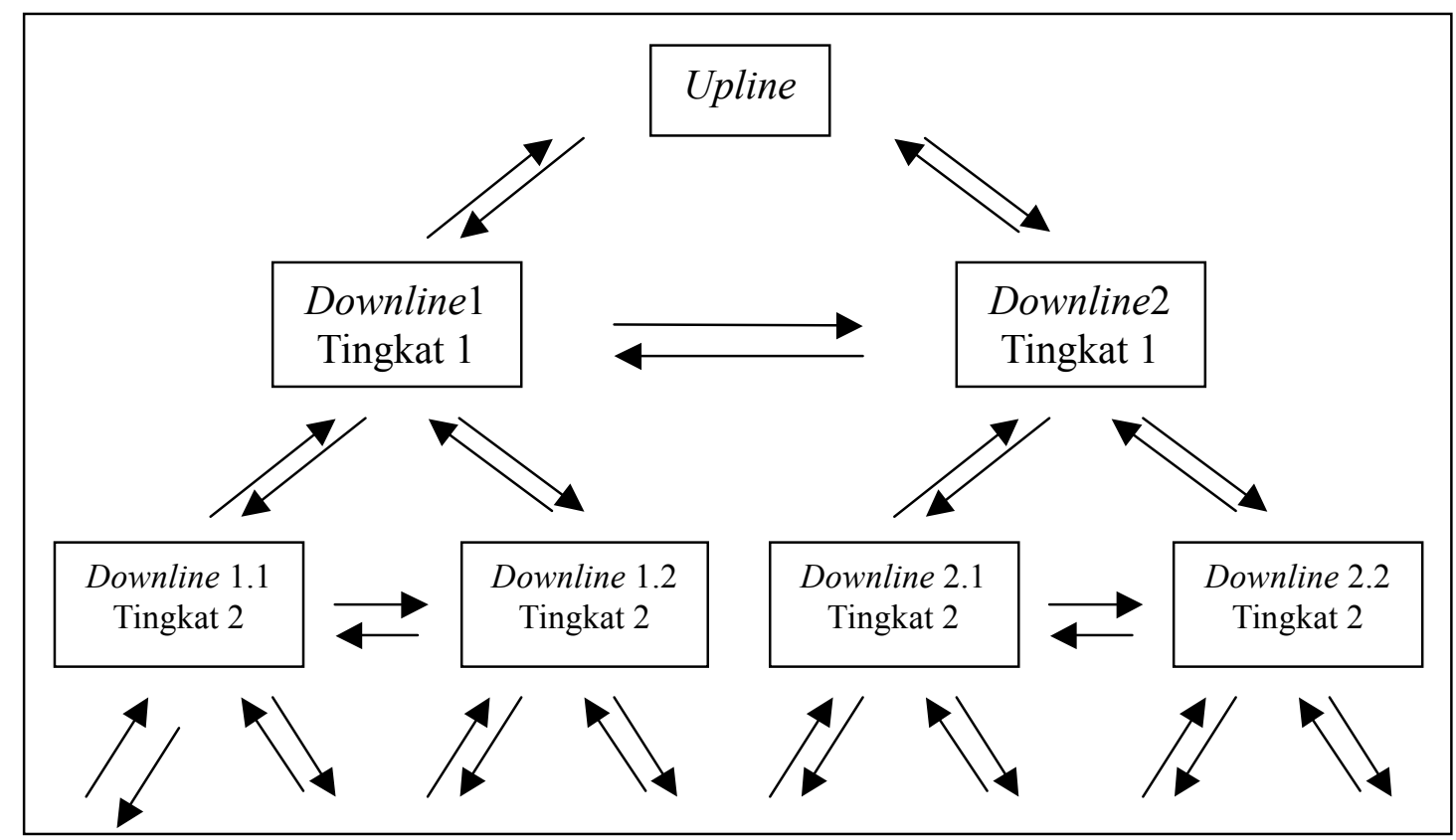

Keterangan :

$\longrightarrow$ Menunjukkan adanya interaksi dari

Gambar 1. Skema Pembelajaran dengan Penugasan Multi Level Instruction

Implementasi pembelajaran dengan strategi penugasan multi level instruction yang digunakan pada penelitian ini dikembangkan sendiri oleh penulis dengan mengacu pada referensi yang telah ada. Materi ajar satu bab dirancang untuk 3 minggu atau sebanyak 6 kali pertemuan. Pertemuan secara selang seling dilakukan antara pembelajaran regular di kelas kemudian diselingi dengan pembelajaran nonreguler untuk pertemuan berikutnya. Yakni untuk pertemuan pertama, ketiga, dan kelima digunakan untuk kegiatan pembelajaran di kelas menggunakan model kooperatif tipe STAD dengan strategi penugasan multi level instruction. Pertemuan kedua dan keempat masih merupakan kelanjutan dari pembelajaran multi level instruction pada pertemuan sebelumnya berupa penugasan kepada siswa untuk belajar dan melakukan diskusi kelompok antara upline dan downline. Sehingga fase pembelajaran kooperatif 
diselesaikan dalam dua kali pertemuan. Pertemuan keenam digunakan untuk mengevaluasi hasil belajar siswa. Materi diskusi yang diberikan adalah soal-soal berlevel, sesuai dengan tingakatan kesulitan, mulai dari soal level satu, soal level dua, dan soal level tiga. Setiap penugasan berlevel, juga disertai dengan evaluasi berlevel.

Pada beberapa penelitian sebelumnya, telah beberapa kali diangkat pembelajaran multi level sebagai suatu solusi dalam mengefektifkan pembelajaran dengan menggunakan beberapa istilah, disebutkan sebagai "multi level tutorial" (Isnachun, 2010), "model kooperatif multi level" (Nurwidiyanto, 2009), "model pembelajaran multi level tutorial" (Ismiyati, 2011), dan "Multi-level instruction sebagai suatu pendekatan" (NWT Teacher Induction). Keempat istilah tersebut memiliki garis besar yang sama yaitu pembelajaran yang mengacu pada pengembangan pembelajaran tutor sebaya dengan menerapkan sistem penjualan produk dengan cara multi level marketing. Strategi ini akan digunakan oleh penulis dalam penugasan siswa. Maka pada penelitian ini penulis mengistilahkannya dengan strategi penugasan multi level instruction.

Istilah efektivitas diartikan sebagai "tingkat ketercapaian tujuan yang dapat ditunjukkan dengan membandingkan hasil yang diperoleh dengan hasil yang ditargetkan" (Yaumi, 2013). Sedangkan kata efektif berkaitan dengan "usaha atau tindakan yang berhasil atau tepat guna" (Suharso, 2005). Terkait dengan pembelajaran, keefektifan pembelajaran berarti ketercapaian tujuan pembelajaran untuk memperoleh tindakan yang tepat guna. "Keefektifan pembelajaran terdiri dari empat indikator, yaitu Quality of Instruction, Appropriate of instruction (Kesesuaian tingkat pembelajaran), Incentive (Insentif), dan Time" Slavin (dalam Patta, 2013). Dalam rangka untuk mengefektifkan pembelajaran, beberapa strategi yang dapat digunakan yaitu reinforcement, prinsip Premack, pemilihan waktu belajar, efek kepertamaan dan kebaharuan. Strategi reinforcement didefinisikan sebagai "setiap konsekuensi yang memperkuat perilaku" (Slavin, 2008). Reinforcement dapat digunakan dalam pembelajaran untuk meningkatkan frekuensi perilaku yang dinginkan. Prinsip Premack adalah "aturan yang menyatakan bahwa kegiatan yang menyenangkan dapat digunakan untuk memperkuat keikutsertaan dalam kegiatan yang kurang menyenangkan" (Slavin, 2008). Sebuah penelitian mengemukakan bahwa "terdapat hubungan positif dan signifikan antara antara manajemen waktu belajar terhadap prestasi belajar siswa" (Suryani, 2009). Primacy effect (efek kepertamaan) dan recency effect (efek 
kebaharuan), masing-masing diartikan sebagai "primacy effect adalah kecenderungan lebih mudah mengingat hal yang pertama dalam daftar daripada hal lain, dan recency effect (efek kebaharuan) merupakan kecenderungan lebih mudah mengingat hal yang terakhir dalam daftar daripada hal lain" (Slavin, 2008). Terkait dengan keefektifan pembelajaran, kriteria keefektifan yang ditentukan dalam penelitian ini terdiri atas dua jenis yakni kriteria efektif untuk setiap indikator keefektifan pembelajaran dan kriteria keefektifan pembelajaran. Kriteria efektif untuk setiap indikator (hasil belajar, respon, aktifitas, sikap dan keterlaksanaan pembelajaran). Untuk hasil belajar, kriteria seorang siswa dikatakan tuntas belajar apabila memenuhi kriteria ketuntasa minimal di sekolah yaitu 73, sedangkan ketuntasan klasikal apabila minimal 80\% siswa di kelas telah mencapai skor ketuntasan. Untuk respon siswa, dikatakan efektif apabila secara deskriptif skor respon siswa berada minimal pada kategori "cenderung positif”. Untuk aktifitas siswa, dikatakan efektif apabila secara deskriptif skor siswa minimal berada pada kategori "baik". Untuk sikap siswa, sikap siswa dikatakan efektif apabila secara deskriptif skor sikap minimal berada pada kategori "baik". Adapun untuk keterlaksanaan pembelajaran dikatakan efektif jika rata-rata skor yang diperoleh tiap aspek pengamatan kegiatan pembelajaran untuk semua RPP minimal berada pada kategori "baik". Kriteria keefektifan pembelajaran. Keefektifan pembelajaran pada penelitian ini ditinjau dari keterpenuhan aspek hasil belajar dan respon siswa, hasil belajar secara klasikal tuntas dan respon siswa terhadap pembelajaran minimal berada dalam kategori “cenderung positif".

Tujuan penelitian ini adalah untuk mengetahui keefektifan hasil pembelajaran matematika siswa (santri) yang diajarkan dengan pendekatan pembelajaran multi level instruction pada Pondok Pesantren Modern IMMIM Makassar yang dijabarkan sebagai berikut: untuk mengetahui aktifitas siswa dalam proses pembelajaran multi level instruction, untuk mengetahui respon siswa terhadap pembelajaran multi level instruction, dan untuk mengetahui hasil belajar siswa siswa yang diajar dengan pembelajaran multi level instruction.

Penelitian ini diharapkan dapat memberikan manfaat teoritis dan praktis bagi pemerhati pendidikan matematika dalam hal sebagai berikut: sebagai bahan pertimbangan bagi sekolah dalam pengambilan keputusan terkait sistem pembelajaran di pondok pesantren, sebagai bahan pertimbangan bagi guru untuk melaksanakan 
pembelajran matematika melalui pembelajaran multi level instruction, Menumbuhkan kesadaran pembaca, khususnya pendidik yang berinteraksi langsung dengan siswa untuk mencari pembelajaran yang mengefektifkan pembelajaran matematika, dan sebagai bahan rujukan terhadap penelitian relevan selanjutnya terkait pembelajaran multi level instruction.

\section{METODE PENELITIAN}

Jenis penelitian ini adalah kuasi eksperimen dengan tujuan untuk mengetahui pengaruh perlakuan terhadap karakteristik subjek yang diinginkan oleh penulis.

Dalam penelitian ini akan dibandingkan hasil perlakuan antara dua kelompok, satu kelompok sebagai kelompok eksperimen satu dan kelompok yang lain sebagai kelompok eksperimen dua. Kelompok eksperimen satu diberikan perlakuan berupa pembelajaran STAD dengan pendekatan multi level instruction sedangkan kelompok eksperimen dua diberikan pembelajaran STAD biasa.

Populasi penelitian adalah santri kelas VIII PP IMMIM Makassar yang dipilih dua kelas secara random sebagai unit sampel penelitian. Pengambilan ini dilakukan secara random sederhana sebab tidak ada penempatan kelas khusus untuk siswa yang tergolong cerdas.

Instrument penelitian yang digunakan adalah lembar observasi aktifitas siswa, angket respon siswa dan tes hasil belajar. Lembar observasi aktifitas siswa yang digunakan dibagi menjadi dua yaitu lembar observasi aktifitas siswa dalam kelas yang dipergunakan pada pertemuan pertama, ketiga, kelima, dan keenam untuk mengetahui keaktifan siswa dalam pembelajaran, sedangkan lembar observasi kedua yaitu lembar observasi aktifitas siswa di luar kelas pada saat melaksanakan pembelajaran multi level instruction, dan dipergunakan pada pertemuan kedua dan keempat untuk mengetahui keaktifan siswa dalam pembelajaran. Penilaian terhadap aktifitas siswa terukur dari ratarata nilai siswa dari frekuensi semua aktifitas yang diukur dengan instrument lembar observasi aktifitas siswa dan ditunjukkan dalam bentuk persentase keaktifan siswa. Penilaian terhadap respon siswa terukur dari besarnya rangsangan atau daya pendorong siswa untuk mengikuti pembelajaran yang diberikan. Penilaian terhadap respon siswa ditunjukkan dalam bentuk persentase respon siswa. Instrument tes hasil belajar yang digunakan ada dua macam yaitu tes kemampuan awal dan tes prestasi belajar.

Perangkat pembelajaran dalam penelitian ini adalah buku siswa, LKS dan RPP 
yang divalidasi oleh pakar pendidikan yang ahli di bidangnya untuk menilai kelayakan perangkat yang dibuat. Penelitian ini dilakukan di Pondok Pesantren Modern IMMIM Makassar pada Bulan Mei 2015 selama enam kali pertemuan. Adapun desain yang digunakan dalam penelitian ini sebagai post test only design.

Dalam penelitian ini, penulis mengumpulkan data dengan terjun langsung ke lapangan dengan cara memberikan materi yang samapada masing-masing kelompok sampel. Diawali dengan pemberian tes kemampuan awal pada kedua kelompok, kelompok eksperimen satudibelajarkan dengan menggunakan strategi penugasan multi level instruction, sedangkan kelompok eksperimen dua diberikan penugasan biasa. Setelah materi selesai, kedua kelompok eksperimen diberikan tes hasil belajar, kemudian akan diberikan umpan balik kepada siswa berupa angket respon terhadap pembelajaran yang siswa terima. Data aktifitas dan sikap siswa diperoleh dengan melakukan kegiatan observasi terhadap siswa oleh guru selama kegiatan pembelajaran berlangsung yang ditunjukkan dalam lembar observasi aktifitas siswa dan dokumentasi. Data respon siswa diambil setelah kegiatan pembelajaran selesai yang dikumpulkan dengan menggunakan angket respon siswa. Data ketuntasan mengajar diambil selama pembelajaran dengan pengamatan dan observasi. Adapun data hasil belajar siswa diambil melalui tes hasil belajar di akhir pertemuan, tes hasil belajar yang diberikan berupa tes uraian yang dalam penilannya menggunakan rubrik penilaian.

Data hasil validasi berupa perangkat pembelajaran dan instrument penelitian direvisi dengan memperhatikan saran-saran dari validator. Data hasil penelitian berupa hasil belajar siswa, kemampuan awal, respon siswa, aktifitas siswa, sikap siswa dan ketuntasan pembelajaran dianalisis secara deskriptif rata-rata untuk menunjukkan kecenderungan perilaku yang ditunjukkan oleh siswa. Analisis inferensial bertujuan untuk menganalisis data sampel dimana hasilnya akan digeneralisasikan pada populasi. Suatu kesimpulan dari data sampel yang akan diberlakukan memiliki peluang kesalahan dan kebenaran yang dinyatakan dalam persentase. Dalam penelitian ini, peneliti menggunakan taraf signifikansi 5\% atau dengan tingkat kepercayaan 95\%. Data hasil penelitian berupa hasil tes hasil belajar dan respon siswa akan dianalisis masing-masing kelompok eksperimen, selain dianalisis secara deskriptif, juga dianalisisis secara inferensial. Analisis inferensial dilakukan denga uji kenormalan Shapiro-Wilk dengan taraf signifikansi 5\%. Analisis inferensial selanjutnya dilakukan denga uji homogenitas 
Levene dengan taraf signifikansi 5\%. Analisis inferensial yang terakhir dilakukan adalah uji perbedaan dua rata-rata denga menggunakan uji-t dilakukan dengan taraf signifikansi 5\%.

Kriteria keefektifan yang ditentukan dalam penelitian ini terdiri atas dua jenis yakni kriteria efektif untuk setiap indicator keefektifan pembelajaran dan kriteria keefektifan pembelajaran. Hasil belajar siswa dikatakan tuntas belajar apabila memenuhi kriteria ketuntasa minimal di sekolah yaitu 73, sedangkan ketuntasan klasikal apabila minimal $80 \%$ siswa di kelas telah mencapai skor ketuntasan. Respons siswa dikatakan efektif apabila secara deskriptif skor respons siswa berada pada kategori “cenderung positif”. Aktivitas siswa dikatakan efektif apabila secara deskriptif skor aktifitas siswa minimal berada pada kategori "baik". Sikap siswa dikatakan efektif apabila secara deskriptif skor sikap siswa minimal berada pada kategori "baik". Keterlaksanaan pembelajaran dikatakan efektif jika rata-rata skor yang diperoleh tiap aspek pengamatan kegiatan pembelajaran untuk semua RPP berada pada kategori "baik" atau "sangatbaik." Keefektifan pembelajaran pada penelitian ini ditinjau dari keterpenuhan aspek hasil belajar dan respon siswa. Hasil belajar secara klasikal tuntas dan respon siswa terhadap pembelajaran minimal berada dalam kategori "cenderung positif'.

\section{HASIL DAN PEMBAHASAN}

Hasil belajar matematika siswa kelompok eksperimen satu dan kelompok eksperimen dua secara deskriptif keduanya memenuhi ketuntasan klasikal, namun dari segi persentase siswa yang tuntas, pada kelompok eksperimen satu lebih banyak dibanding kelompok eksperimen dua. Hal ini terlihat dari aktifitas kelompok eksperimen yang berlomba-lomba dalam menyelesaikan beragam penugasan multi level instruction yang diberikan dibanding kelompok eksperimen dua yang menerima penugasan biasa. Selain itu aktifitas tutor sebaya dan kebebasan siswa dalam memilih waktu dan tempat pembelajaran pada saat kegiatan bermulti level instruction memberikan kesempatan kepada siswa untuk menentukan sendiri kesiapan mereka dalam melakukan penyetoran penugasan.

Respon siswa kelompok eksperimen dua untuk aspek proses dan hasil memenuhi kriteria cenderung positif. Kategori respon skor rata-rata kelompok eksperimen dua secara deskriptif sama dengan kategori skor rata-rata kelompok eksperimen satu. 
Namun dari segi angka, skor rata-rata respon kelompok eksperimen dua lebih tinggi dibanding skor rata-rata kelompok eksperimen satu, hasil ini dapat dijelaskan sebab siswa pada kelas eksperimen satu memberikan respon yang kurang karena mereka harus belajar mandiri dan mendapatkan target materi dan tugas yang harus dipelajari secara mandiri.

Skor rata-rata aktifitas siswa untuk aktifitas yang diharapkan pada kelompok eksperimen satu dan dua memiliki kriteria yang sama, namun secara deskriptif skor rata-rata kelompok eksperimen satu lebih tinggi dibanding kelompok eksperimen dua. Hal ini menunjukkan bahwa siswa pada kelas eksperimen satu lebih aktif dan lebih merespon pembelajaran di kelas, hal ini didukung pada pemberian bonus, penghargaan dan atribut yang beragam tiap pertemuan terhadap bonus kepemimpinan dan kelompok multi level pada pertemuan multi level di pertemuan sebelumnya. Namun aktifitas siswa untuk aktifitas yang tidak diharapkan pada kelompok eksperimen satu dan kelompok eksperimen dua memiliki kriteria yang sama, namun secara deskriptif skor rata-rata kelompok eksperimen satu lebih tinggi dibanding kelompok eksperimen dua. Hal ini menunjukkan bahwa kelompok ekperimen satu lebih hyper aktif, sehingga diperlukan kecakapan guru dalam mengontrol jalannya proses pembelajaran.

Aktifitas siswa kelompok eksperimen satu, dalam melakukan kegiatan penugasan multi level instruction, diamati secara langsung oleh penulis di dalam kelas dan kegiatan penyetoran penugasan multi level instruction di luar kelas. Siswa secara bertahap diberikan lembar tugas berlevel untuk didiskusikan secara kelompok, kemudian mengerjakan evaluasi berlevel. Aktifitas interaksi dan penyetoran penugasan berlevel siswa, selama rentang waktu penelitian yang disediakan dicatat oleh peneliti dan dirangkum dalam table hasil rekapitulasi kegiatan interaksi multi level instruction siswa pada table 4.24. Berdasarkan hasil pengukuran aktivitas siswa dalam melakukan pembelajaran dengan penugasan multi level instruction yakni pada kelompok eksperimen diperoleh fakta-fakta bahwa siswa berantusias dan termotivasi untuk melakukan penyetoran tugas berlevel dan berlomba-lomba meraih penghargaan terbanyak. Selain itu ditemukan pula bahwa terjadi diskusi lintas kelompok, beberapa siswa mampu menyelesaikan sendiri dengan baik penugasan berlevel lebih cepat dalam waktu satu minggu pada materi yang telah dipersiapkan untuk 5 pertemuan. Dalam kegiatan penugasan multi level, ditemukan muncul downline tingkat tiga. 
Secara inferensial rata-rata hasil belajar siswa yang diajarkan dengan pembelajaran kooperatif tipe STAD dengan pendekatan saintifik strategi penugasan multi level instruction lebih tinggi dibanding rata-rata hasil belajar siswa yang diajarkan dengan pembelajaran kooperatif tipe STAD dengan pendekatan saintifik strategi penugasan biasa. Adapun respon siswa secara inferensial tidak terdapat perbedaan yang siginifikan baik kelompok eksperimen satu dan kelompok eksperimen dua terhadap pembelajaran yang diberikan.

\section{SIMPULAN}

Hasil belajar matematika siswa kelompok eksperimen satu dan kelompok eksperimen dua, secara deskriptif keduanya memenuhi ketuntasan klasikal. Hasil analisis inferensial menunjukkan bahwa hasil belajar kelompok eksperimen satu lebih tinggi dibanding hasil belajar kelompok eksperimen dua. Respon siswa kelompok eksperimen satu dan kelompok eksperimen dua, secara deskriptif kelompok eksperimen satu memiliki kategori yang sama dengan kelompok eksperimen dua. Namun dari skor rata-rata, respon kelompok eksperimen dua lebih tinggi dibanding skor rata-rata kelompok eksperimen satu. Secara inferensial, tidak terdapat perbedaan respon antara kelompok eksperimen satu dan kelompok eksperimen dua. Aktifitas siswa untuk aspek aktifitas yang diharapkan pada kelompok eksperimen satu dan dua memiliki kriteria yang sama, namun secara deskriptif rata-rata, rata-rata skor kelompok eksperimen satu lebih tinggi dibanding kelompok eksperimen dua. Sikap siswa untuk kelompok eksperimen satu dan dua pada aspek kedisiplinan dan rasa hormat serta perhatian adalah sama. Sedangkan untuk aspek ketekunan dan tanggung jawab, kelompok eksperimen dua memiliki kategori penilaian yang lebih baik dibanding kelompok eksperimen satu.

Untuk kelompok eksperimen satu, hasil belajar siswa memenuhi kriteria ketuntasan dan respon siswa berada pada kategori "cenderung positif" sehingga disimpulkan pembelajaran kooperatif tipe STAD dengan pendekatan saintifik strategi penugasan multi level instruction dikatakan efektif untuk diterapkan dalam pembelajaran. Sedangkan kelompok eksperimen dua, hasil belajar siswa memenuhi kriteria ketuntasan dan respon siswa berada pada kategori "cukup positif" sehingga disimpulkan pembelajaran kooperatif tipe STAD dengan pendekatan saintifik strategi penugasan biasa dikatakan efektif untuk diterapkan dalam pembelajaran.

Perbandingan keefektifan antara kelompok eksperimen satu dan kelompok 
eksperimen dua, dari aspek hasil belajar, kelompok eksperimen satu memiliki keefektifan yang lebih tinggi dibanding kelompok eksperimen dua. Sedangkan dari aspek respon siswa, kelompok eksperimen dua lebih tinggi dibanding kelompok eksperimen satu. Berdasarkan kesimpulan tersebut maka diberikan beberapa saran agar pembelajaran dengan penugasan multi level instruction dapat direkomendasikan untuk sekolah berasrama, pemberian bonus dan penghargaan yang menarik akan menambah motivasi siswa dalam melakukan pembelajaran multi level instruction, penugasan yang diberikan dapat dibuat lebih bervariasi untuk menambah pengetahuan siswa mengenai materi yang diajarkan, pengawasan dari guru dibutuhkan untuk memastikan keterlaksanaan pembelajaran dan menghindari adanya miskonsepsi siswa terhadap materi dalam pembelajaran multi level instruction, mengingat siswa senang memiliki kebebasan memilih waktu belajar dan menyetor tugas matematika kepada guru, sehingga hal ini membutuhkan kehadiran guru yang sedapat mungkin selalu berada di asrama, dengan strategi dan manajemen pembelajaran yang terencana, siswa yang cerdas dapat dengan cepat menyelesaikan materi ajar untuk satu semester lebih awal dan dapat diperbantukan untuk membantu siswa yang lain dalam memahami materi yang diajarkan.

\section{DAFTAR RUJUKAN}

Ahmad. (2015). Komparasi Pembelajaran Matematika Materi Aritmatika Sosial Melalui Penerapan Model Pembelajaran Kooperatif Tipe Jigsaw dan NHT Kelas VII SMP Negeri 4 Maritengngae Kabupaten Sidrap. Tesis, Universitas Negeri Makassar, Makassar.

Ardin. (2013). Keefektifan Pembelajaran Matematika Realistik Setting Kooperatif Tipe NHT pada Materi Pokok Ruang Dimensi Tiga. Tesis, Universitas Negeri Makassar, Makassar.

Budiningsih, C.A. (2005). Belajar dan Pembelajaran. Jakarta: PT Rineka Cipta.

Duran, D. (2010). Cooperative interactions in peer tutoring: Patterns and sequences in paired writing. Middle Grades Research Journal, 5 (1).

Evans, W \& Flower, J. (2001). Peer tutoring in first year undergradute mathematics. International Journal Mah, Educ, Sci, Technol, 32 (2).

Gafar, L. (2013). Keefektifan Pembelajaran Kooperatif Tipe Jigsaw Untuk Materi Bangun Ruang Sisi Datar Di Kelas Vii Sekolah Menengah Pertama. Universitas Negeri Surabaya, Surabaya. 
Gordon \& Edward, E. (2005). Peer Tutoring: a Teachers's Resource Guide. Scarecrow Education, USA.

Iskandar, A. M. (2013). Interpersonal Communication on Applied. Jakarta: Orbit Publishing.

Isnachun, M. (2010). Efektifitas Multi Level Tutorial Terhadap Hasil Belajar Siswa pada Materi Matriks Kelas X IPS 3 SMK Negeri Semarang. IKIP PGRI, Semarang.

Ismiyati. (2011). Efektivitas multi level tutorial dalam meningkatkan hasil belajar peserta didik pada materi himpunan kelas vii mts nurul huda dempet. IAIN Walisongo, Semarang.

Johnson, L. (2008). Pengajaran yang kreatif dan menarik (original title: Teaching Outside the Box, How to Grab Your Students by Their Brains). Jakarta: PT Indeks.

Lafleur, P. \& Bluffs, C. (2010). Peer Tutoring: Student Achievement, Confidence and The Teacher's Role. Action Research Project Report. University of NebraskaLincoln: Department of Mathemacis

Maisaroh \& Rostrieningsih. (2010). Peningkatan Hasil Belajar Siswa Dengan Menggunakan Metode Pembelajaran Active Learning Tipe Quiz Team pada Mata Pelajaran Keterampilan Dasar Komunikasi di SMK Negeri 1 Bogor. Jurnal Ekonomi \& Pendidikan, 8 (2): 157 - 172.

Nurwidiyanto. (2009). Perbandingan Keefektifan Model Kooperatif Multi Level, Model Group Investigation, dan Model Advance Organizer Terhadap Hasil Belajar Dengan Materi Penerapan Fungsi Linier dan Kuadrat pada Matematika Ekonomi Siswa Kelas Xi Semester Genap Program Kejuruan Akuntansi dan Penjualan SMK YPPM Boja Kabupaten Kendal Tahun 2009/2010. IKIP PGRI, Semarang.

NWT Teacher Induction. Professional Advice Multi-level InstructionH. Diakses 4 Februari 2014, dari http://www.newteachersnwt.ca/professional_advice2.html

YPatta, R. (2013). Efektivitas Penerapan Pembelajaran Kooperatif Tipe Two Stay Two Stray dan Tipe Jigsaw Pada Materi Bangun Datar Siswa Kelas VII Smp. Tesis, Universitas Negeri Makassar, Makassar.

Peterson, M. (2002). Pricples of Authentic Multi-Level Instructionor. Michigan, Multilevel teaching wok group whole schooling consortium.

Petocz, P., Duke, M., Bilgin, A., \& Reid, A. (2012). Exploring peer learning (student to student, lecturer to lecturer). Asian Social Science, 21838 (114). Macquire University: Canadian Center of Science and Education.

Rusman. (2013). Model-Model Pembelajaran: Mengembangkan Profesionalisme Guru. Jakarta: PT Raja Grafindo Persada. 
Tri Wibowo, B.S. (2013). Psikologi Pendidikan. Jakarta: Fajar Interpratama Mandiri. (Original work published Santrock, J.W. 2004)

Saputro, W.A. (2005). Pengembangan Perangkat Pembelajaran Kooperatif Tipe STAD Pada Pokok Bahasan Sistem Persamaan Linear Dua Variabel Kelas II SLTP. Universitas Negeri Surabaya, Surabaya

Siswoyo, D. (2013). Belajar dan Pembelajaran. Diakses 11 Februari 2015, dari http://dedi26.blogspot.com/2013/02/apa-itu-matematika-pengertian.html

Slavin, R. E. (2010). Cooperative Learning: Teori, Riset dan Praktik. Bandung: Nusa Media.

Slavin, R. E. (2008). Psikologi Pendidikan Teori dan Praktik. Jakarta: PT Indeks.

Somalinggi. (2013). Komparasi Model Pembelajaran Kooperatif Tipe Jigsaw Dan Tipe Team Assisted Individualization (TAI) Berbantuan Multimedia Interaktif terhadap Kemampuan Berpikir Kritis dan Kreatif Matematis Pada Siswa Smp Kelas VIII. Tesis. Universitas Negeri Makassar, Makassar

Sudijono, A. (2005). Pengantar Evaluasi Pendidikan. Jakarta: PT RajaGrafindo Persada.

Sudjana, N., \& Rivai, A. (2001). Media Pengajaran: Penggunaan dan Pembuatannya. Bandung: Sinar Baru Algensindo.

Suharso dan Retnoningsih, A. (2005). Kamus Besar Bahasa Indonesia (Ed. Lux). Semarang: CV. Widya Karya.

Suryani, A. (2009). Pengaruh Manajemen Waktu dan Motivasi Belajar terhadap Prestasi Belajar Kimia Siswa Kelas X MAN Maguwoharjo Sleman. Skripsi, UIN Sunan Kalijaga, Yogyakarta.

Topping, K. J. (2011). The effectiveness of peer tutoring in further and higher education (Vol. 32, No. 3 p. 321-345). Kluwer Academic Publisher, Netherland.

Tiro, M. A. (2010). Cara Efektif Belajar Matematika. Makassar: Andira Publisher.

Tiro, M. A., \& Sukarna. (2013). Metode Ellips dalam Analisis Data Kuantitatif. Makassar: Andira Publisher.

Yaumi, M. (2013). Prinsip-Prinsip Desain Pembelajaran Disesuaikan dengan Kurikulum 2013. Jakarta: Kencana.

Young, E. (2011). On Site Peer Tutoring in Mathematic Content Courses for Pre-service Teachers. IUMPST, Vol. 2 (February 2011). Texas: College Research Enchancement Program. 
Mahmud, Syamsuadi \& Nursakiah, Pembelajaran Kooeperatof STAD dengan Strategi Penugasan Multi Level Instruction pada materi Matematika 